\title{
Identifikasi Kesalahan Pekerjaan Siswa Kelas V SD YPK Diaspora Arso 7 Pada Materi Pembagian Pecahan Yang Ditinjau Dari Perbedaan Kemampuan
}

\author{
Dewi Kristika Findia Ning Tyas \\ Program Studi Pendidikan Matematika FKIP UNCEN
}

Email: dewikristikafindy@yahoo.co.id

\begin{abstract}
Abstrak:Penelitian ini merupakan penelitian deskriptif dengan pendekatan kualitatif. Tujuan penelitian ini yaitu untuk mendeskripsikan kesalahan apa saja yang dilakukan siswa serta penyebab siswa melakukan kesalahan dalam menyelesaikan soal-soal pembagian pecahan melalui identifikasi pekerjaan siswa kelas V SD YPK Diaspora Arso 7 yang ditinjau dari perbedaan kemampuan siswa. Subjek pada penelitian ini berjumlah tiga orang yang diambil dari siswa kelas V SD YPK Diaspora Arso 7. Pengumpulan data diambil dengan metode tes tertulis dan wawancara. Berdasarkan hasil penelitian diperoleh bahwa (1) Ditemukan kesalahan-kesalahan yang dilakukan oleh siswa adalah (a) siswa kemampuan tinggi: kesalahan hitung yaitu kesalahan dalam membagi. (b) siswa kemampuan sedang: kesalahan konseptual yaitu kesalahan dalam mengubah pecahan campuran menjadi pecahan biasa (c) siswa kemampuan rendah: kesalahan konseptual yaitu kesalahan dalam mengubah pecahan campuran menjadi pecahan biasa dan tidak mengubah operasi pembagian menjadi perkalian setelah membalik pecahan pembagi (2) faktor penyebab terjadinya kesalahan adalah (a) siswa kemampuan tinggi, yaitu: siswa tergesa-gesa dan kurang teliti dalam mengerjakan soal (b) siswa kemampuan sedang, yaitu: siswa tidak memahami dengan baik materi mengubah pecahan campuran menjadi pecahan biasa (c) siswa kemampuan rendah, yaitu: siswa tidak memahami dengan baik materi materi mengubah pecahan campuran menjadi pecahan biasa dan konsep pembagian pecahan dimana setelah membalik pecahan pembagi maka operasi pembagian diubah menjadi perkalian.
\end{abstract}

Kata Kunci: identifikasi kesalahan, perbedaan kemampuan, pembagian pecahan.

\section{PENDAHULUAN}

Materi pembagian pecahan merupakan materi yang sangat penting dan siswa akan mempelajarinya disetiap jenjang kelas SD, tidak hanya itu materi pecahan merupakan dasar yang sangat penting untuk siswa mempelajari materi selanjutnya. Dalam kehidupan sehari-haripun kita tidak terlepas dari permasalahan yang berkaitan dengan materi pembagian pecahan. Dengan beberapa alasan tersebut maka sangat penting bagi siswa dapat memahami materi pecahan dan diharapkan siswa dapat memecahlan soal ataupun permasalahan sehari-hari yang berkaitan dengan materi pembagian pecahan.

Berdasarkan hasil observasi awal di sekolah ternyata masih banyak siswa yang melakukan kesalahan dalam menyelesaikan soal-soal yang berkaitan dengan pembagian pecahan, untuk itu perlu diidentifikasi dimana letak kesalahan yang dilakukan siswa dan dicari faktor-faktor apa saja yang menyebabkan terjadinya kesalahan.

Pertanyaan Penelitian

Jurnal IImiah Mandala Education
1. Jenis-jenis kesalahan apa saja yang dilakukan siswa kelas V SD YPK Diaspora Arso 7 dalam menyelesaikan soal pembagian pecahan yang ditinjau dari perbedaan kemampuan siswa?

2. Faktor apa saja yang menyebabkan terjadinya kesalahan siswa kelas V SD YPK Diaspora Arso 7 dalam menyelesaikan soal pembagian pecahan yang ditinjau dari perbedaan kemampuan siswa?

\section{Tujuan Penelitian}

1. Untuk mendeskripsikan jenis-jenis kesalahan apa saja yang dilakukan siswa kelas V SD YPK Diaspora Arso 7 dalam menyelesaikan soal pembagian pecahan yang ditinjau dari perbedaan kemampuan siswa.

2. Untuk mengetahui faktor apa saja yang menyebabkan terjadinya kesalahan siswa kelas V SD YPK Diaspora Arso 7 dalam menyelesaikan soal pembagian pecahan yang ditinjau dari perbedaan kemampuan siswa. 


\section{KAJIAN PUSTAKA \\ Pengertian Identifikasi Kesalahan}

Kesalahan dapat diartikan sebagai penyimpangan terhadap suatu yang benar, prosedur yang ditetapkan sebelumnya, atau penyimpangan dari suatu yang diharapkan (Sitti, 2012:2). Agar kesalahan tersebut tidak terulang di kemudian hari, maka perlu diidentifikasi kesalahan-kesalahan yang terjadi. Menurut Yasyin (1995:119) identifikasi adalah penetapan identitas, dalam penelitian ini identifikasi yang dimaksud adalah identifikasi mengenai jenis-jenis kesalahan yang dilakukan siswa dan faktorfaktor penyebab kesalahan siswa dalam menyelesaikan soal-soal peluang suatu kejadian.

Berdasarkan pendapat para ahli di atas, dapat diambil kesimpulan identifikasi kesalahan adalah penetapan penyimpangan jenis-jenis kesalahan siswa dalam menyelesaikan soal peluang suatu kejadian beserta penyebabnya. Dengan demikian, diharapkan bahwa dari kesalahan-kesalahan siswa yang ditemukan dalam menyelesaikan soal peluang suatu kejadian dapat dijadikan sebagai bahan informasi dan masukan bagi guru dan siswa demi perbaikan masa depan yang akan datang.

\section{Kesalahan dalam Menyelesaikan Soal Matematika}

\section{Lerner}

(Sunarsi,

2009:19)

mengemukakan berbagai kesalahan umum yang dilakukan oleh anak dalam mengerjakan tugas-tugas matematika, yaitu kurangnya pengetahuan tentang simbol, kurangnya pemahaman tentang nilai tempat, penggunaan proses yang keliru, kesalahan perhitungan, dan tulisan yang tidak dapat dibaca sehingga siswa melakukan kekeliruan karena tidak mampu lagi membaca tulisannya sendiri.

Sedangkan menurut Sriati (Sunarsi, 2009:19), kesalahan siswa dalam mengerjakan soal matematika adalah:

a. Kesalahan terjemahan

Adalah kesalahan mengubah informasi ke ungkapan matematika atau kesalahan dalam memberi makna suatu ungkapan matematika.

b. Kesalahan konsep

Adalah kesalahan memahami suatu gagasan yang tidak dijelaskan secara jelas.

c. Kesalahan sistematik

Adalah kesalahan yang berkaitan dengan pemilihan teknik pengerjaan yang salah.

d. Kesalahan strategi

Adalah kesalahan yang terjadi jika siswa memilih cara yang tidak tepat.

e. Kesalahan tanda

Adalah kesalahan dalam memberikan atau menulis tanda atau notasi matematika.

f. Kesalahan hitung

Adalah kesalahan menghitung dalam operasi matematika.

Dalam konteks pembelajaran, kesalahan yang sering kali dilakukan oleh siswa yaitu kesalahan konsep. Kesalahan mempelajari suatu konsep terdahulu akan berpengaruh terhadap pemahaman konsep berikutnya karena matematika merupakan pelajaran yang terstruktur. Menurut Gabel (Rangga, 2013:17) kesalahan konsep yang dimiliki oleh siswa dapat disebabkan oleh:

a. Hasil pengamatan terhadap fenomena alam disekitar siswa, kadang-kadang perasaan dapat menipu mereka dalam memahami fenomena tesebut.

b. Konsep yang diajarkan tidak terjangkau oleh perkembangan mental siswa. Artinya, informasi yang dari luar dan dalam kelas berpotensi sebagai sumber kesalahan konsep siswa, jika informasi yang didapat siswa tidak menjadikan gambaran mental siswa menjadi benar.

Menurut Kastolan (Rangga, 2013:17) bentuk-bentuk kesalahan yang dilakukan oleh siswa adalah sebagai berikut:

a. Kesalahan Konseptual

Kesalahan konseptual adalah kesalahan yang dilakukan dalam menafsirkan istilah, konsep dan prinsip atau salah dalam menggunakan istilah, konsep dan prinsip.

b. Kesalahan Prosedural

Kesalahan prosedural adalah kesalahan dalam menyusun langkah-langkah yang tepat untuk menjawab suatu masalah.

\section{Pengertian Perbedaan Kemampuan}

Perbedaan berasal dari kata "beda" yang berarti tidak sama, sedangkan kemampuan berasal dari kata "mampu" yang menurut Yasyin (1995:182) berarti sanggup. Jadi, dalam penelitian ini, perbedaan kemampuan 
siswa didefinisikan sebagai kesanggupan siswa dalam menyelesaikan soal materi pembagian pecahan yang diukur dari adanya perbedaan nilai masing-masing siswa dimana terdapat siswa yang memiliki kemampuan yang tinggi, kemampuan yang sedang dan kemampuan yang rendah.

\section{METODE PENELITIAN}

Penelitian ini dilaksanakan di SD YPK Diaspora Arso 7 Kabupaten Keerom. Penelitian ini merupakan penelitian deskriptif dengan pendekatan kualitatif.

Dalam penelitian ini, subjek penelitian diambil 3 siswa dari 20 siswa kelas V SD YPK Diaspora Arso 7 Kabupaten Keerom. Sesuai tujuan penelitian, maka untuk menentukan subjek penelitian digunakan teknik purposive sampling (pengambilan subjek berdasarkan tujuan) dengan menetapkan kriteria pemilihan subjek Kriteria subjek dalam penelitian ini adalah sebagai berikut:

1. Satu (1) subjek dengan kemampuan tinggi (SKT) dengan nilai $\geq 80$, satu (1) subjek dengan kemampuan sedang (SKS) dengan 60 nilai < 80, dan satu (1) subjek dengan kemampuan rendah (SKR) dengan nilai < 60. (Putri, 2012)

2. Subjek dapat mengutarakan pendapat secara lisan.

3. Subjek merupakan siswa yang selalu mengikuti kegiatan pembelajaran matematika di sekolah.

Instrumen yang digunakan dalam penelitian ini, yaitu:

1. Instrumen Utama

Dalam penelitian kualitatif, instrumen utamanya adalah peneliti sendiri dan tidak dapat digantikan dengan instrumen lainnya.

2. Instrument bantu

Terdiri dari lembar soal (tes) dan pedoman wawancara

Teknik yang digunakan dalam pengumpulan data adalah teknik tes tertulis dan teknik wawancara. Pada penelitian kualitatif, pemeriksaan keabsahan data salah satunya bisa dilakukan dengan triangulasi. Triangulasi yang digunakan dalam penelitian ini adalah triangulasi teknik.
HASIL

Berikut ini akan disajikan rangkuman hasil analisis secara menyeluruh, yaitu:

\section{Subjek 1 (TD)}

Dari 2 soal yang dikerjakan subjek 1 (SKT), diperoleh hasil kesalahankesalahan yang dilakukan subjek seperti pada tabel berikut ini.

Tabel 1 tabel jenis-jenis kesalahan SKT

\begin{tabular}{|c|c|l|}
\hline $\begin{array}{c}\text { Nomor } \\
\text { soal }\end{array}$ & Butir soal & $\begin{array}{l}\text { Jenis kesalahan yang } \\
\text { ditemukan }\end{array}$ \\
\hline 1 & $\frac{2}{5}: \frac{3}{15}$ & Tidak terdapat kesalahan \\
\hline 2 & $1 \frac{4}{6}: 3 \frac{1}{3}$ & $\begin{array}{l}\text { Kesalah hitung, subjek salah } \\
\text { dalam membagi }\end{array}$ \\
\hline
\end{tabular}

\section{Subjek 2 (WR)}

Dari 2 soal yang dikerjakan subjek 2 (SKS), diperoleh hasil kesalahankesalahan yang dilakukan subjek seperti pada tabel berikut ini.

Tabel 2 tabel jenis-jenis kesalahan SKS

\begin{tabular}{|c|c|l|}
\hline $\begin{array}{c}\text { Nomor } \\
\text { soal }\end{array}$ & Butir soal & $\begin{array}{l}\text { Jenis kesalahan yang } \\
\text { ditemukan }\end{array}$ \\
\hline 1 & $\frac{2}{5}: \frac{3}{15}$ & Tidak terdapat kesalahan \\
\hline 2 & $1 \frac{4}{6}: 3 \frac{1}{3}$ & $\begin{array}{l}\text { Kesalahan konsep, subjek salah } \\
\text { dalam merubah pecahan } \\
\text { campuran ke dalam bentuk } \\
\text { pecahan biasa }\end{array}$ \\
\hline
\end{tabular}

\section{Subjek 3 (YL)}

Dari 2 soal yang dikerjakan subjek 2 (SKS), diperoleh hasil kesalahankesalahan yang dilakukan subjek seperti pada tabel berikut ini.

Tabel 3 tabel jenis-jenis kesalahan SKR

\begin{tabular}{|c|c|l|}
\hline $\begin{array}{c}\text { Nomor } \\
\text { soal }\end{array}$ & Butir soal & $\begin{array}{l}\text { Jenis kesalahan yang } \\
\text { ditemukan }\end{array}$ \\
\hline 1 & $\frac{2}{5}: \frac{3}{15}$ & $\begin{array}{l}\text { Kesalahan konsep, subjek tidak } \\
\text { merubah bentuk operasi } \\
\text { pembagian menjadi perkalian } \\
\text { setelah membalik pecahan } \\
\text { yang dibagi. }\end{array}$ \\
\hline 2 & $1 \frac{4}{6}: \frac{3}{3}$ & $\begin{array}{l}\text { Kesalahan konsep, subjek salah } \\
\text { dalam merubah pecahan } \\
\text { campuran menjadi pecahan } \\
\text { biasa dan subjek tidak merubah } \\
\text { bentuk operasi pembagian } \\
\text { menjadi perkalian setelah } \\
\text { membalik pecahan yang } \\
\text { dibagi. }\end{array}$ \\
\hline
\end{tabular}

PEMBAHASAN 
Kesalahan konseptual, meliputi:

Kesalahan dalam merubah bentuk pecahan campuran menjadi pecahan biasa

Kesalahan dalam merubah bentuk pecahan campuran menjadi pecahan biasa

dilakukan oleh subjek 2 (SKS) dan subjek 3 (SKR).

Faktor penyebab kesalahan adalah subjek tidak memahami mengubah bentuk pecahan campuran ke dalam bentuk pecahan biasa.

\section{Kesalahan tidak merubah operasi pembagian menjadi perkalian setelah pecahan pembagi dibalik}

Kesalahan tidak merubah operasi pembagian menjadi perkalian setelah pecahan pembagi dibalik dilakukan oleh subjek 3 (SKR).

Faktor penyebab kesalahan adalah subjek tidak memahami konsep pembagian pecahan, jika pecahan pembagin dibalik maka operasi pembagian diganti menjadi operasi perkalian.

\section{Kesalahan hitung}

Kesalahan hitung dilakukan oleh subjek 1 (SKT)

Kesalahan terjadi karena subjek tergesa-gesa dan kurang teliti

\section{Simpulan}

Jenis-jenis kesalahan yang dilakukan oleh siswa dalam menyelesaikan soal pembagian pecahan yang ditinjau dari perbedaan kemampuan siswa.

Subjek 1 (SKT)

Kesalahan hitung

\section{Subjek 2 (SKS)}

Kesalahan yang dilakukan subjek 2 (SKS) adalah kesalahan konseptual, yaitu:

Salah dalam mengubah bentuk pecahan campuran menjadi pecahan biasa

\section{Subjek 3 (SKR)}

Kesalahan yang dilakukan subjek 3 (SKR) adalah kesalahan konseptual,

yaitu: Salah dalam mengubah bentuk pecahan campuran menjadi pecahan biasa

dan mengubah operasi pembagian menjadi perkalian setelah membalik pecahan pembagi Faktor penyebab terjadinya kesalahan yang dilakukan siswa dalam menyelesaikan soalsoal pembagian pecahan yang ditinjau dari perbedaan kemampuan siswa.

\section{Subjek 1 (SKT)}

Siswa terlalu tergesa-gesa dalam mengerjakan soal.
Siswa kurang teliti dalam melakukan operasi pembagian.

\section{Subjek 2 (SKS)}

siswa tidak memahami dengan baik materi mengubah pecahan campuran menjadi pecahan biasa

\section{Subjek 3 (SKR)}

siswa tidak memahami dengan baik materi mengubah pecahan campuran menjadi pecahan biasa dan konsep pembagian pecahan

\section{Saran}

Berdasarkan kesimpulan di atas, dapat diberikan beberapa saran sebagai berikut.

Kepada guru matematika yang mengajar kelas V SD diharapkan dapat lebih memperhatikan pembelajaran mengenai pokok bahasan pecahan khususnya materi pembagian pecahan dengan memberikan contoh-contoh soal atau latihan-latihan kepada siswa. Dengan tujuan dapat mengurangi jumlah siswa yang akan melakukan kesalahan-kesalahan dalam menyelesaikan soal pembagian pecahan.

Guru sebaiknya mengecek pemahaman siswa akan materi prasyarat sebelum mengajar, agar siswa dengan mudah mnerima materi yang baru.

Kepada peserta didik diharapkan untuk memperbanyak latihan soal mengenai materi pembagian pecahan, agar tidak melakukan kesalahan-kesalahan yang sama lagi.

\section{DAFTAR PUSTAKA}

Aunurrahman. 2012. Belajar dan Pembelajaran. Bandung: Alfabeta

Putri. 2012. Identifikasi Kemampuan Siswa dalam Memecahkan Masalah di Kelas VIII Berdasarkan Taksonomi SOLO. Unesa. Jurnal. Diakses pada 25 Agustus 2013

Rangga, G. 2013. Analisis Kesalahan dan Solusinya Dalam Menyelesaikan Soal Matematika Pada Pokok Bahasan Sistem Persamaan Dua Variabel Pada Siswa Kelas X SMA Negeri 01 Kodi. Nusa tenggara timur. Diakses pada 25 agustus 2013

Sardiman. 2012. Interaksi dan Motivasi Belajar Mengajar. Jakarta: Rajawali Pers

Sitti,dkk. 2012. Analisis Kesalahan Siswa dalam Menyelesaikan Soal Matematika Materi Operasi Pecahan Bentuk Aljabar 
kelas VIII SMP Negeri 2 Malang. Jurnal Universitas Negeri Malang

Soedjadi. 2000. Kiat Pendidikan Matematika Di Indonesia. Jakarta: Direktorat Jenderal Pendidikan Tinggi Departemen Pendidikan Nasional

Sunarsi, A. 2009. Analisis kesalahan dalam menyelesaikan soal pada Materi luas permukaan serta volume prisma dan limas Pada siswa kelas viii semester genap smp negeri 2 Karanganyar Tahun ajaran 2008/2009. Skripsi. Universitas Sebelas Maret Surakarta. Diakses pada 25 agustus 2013

Sugiyono. 2011. Metode Penelitian pendidikan. Bandung: Alfabeta

Sutikno, S. 2013. Belajar dan Pembelajaran. Lombok: Holistika

Suwarto. 2013. Pengembangan Tes Diagnostik Dalam Pembelajaran. Yogyakarta: Pustaka Pelajar

Yasyin, S. 1995. Kamus Pintar Bahasa Indonesia. Surabaya: Amanah 